\title{
Living in a caatinga-rocky field transitional habitat: ecological aspects of the whiptail lizard Cnemidophorus ocellifer (Teiidae) in northeastern Brazil
}

\author{
Vanderlaine A. Menezes' ${ }^{1}$; Monique Van Sluys ${ }^{1}$; Angélica F. Fontes ${ }^{1} \&$ Carlos F. D. Rocha ${ }^{1}$ \\ 1 Laboratório de Vertebrados, Departamento de Ecologia, Universidade do Estado do Rio de Janeiro. Rua São Francisco Xavier \\ 524, Maracanã, 20550-013 Rio de Janeiro, RJ, Brazil. \\ 2 Correspondig author. E-mail: va.menezes@gmail.com
}

\begin{abstract}
The ecology of the active forager lizard Cnemidophorus ocellifer (Spix, 1825) was studied to analyze food habits, thermal ecology and habitat use, in the Morro do Chapéu municipality $\left(11^{\circ} 29^{\prime} \mathrm{S}, 41^{\circ} 07^{\prime} \mathrm{W}\right)$, state of Bahia, Brazil. Lizards $(N=34)$ were collected with rubber bands or with an air rifle and, for each individual, we recorded cloacal temperature $\left(T_{c}\right)$, air temperature $\left(T_{a}\right)\left(1 \mathrm{~cm}\right.$ above the substrate) and substrate temperature $\left(T_{s}\right)$ (to nearest $\left.0.2^{\circ} \mathrm{C}\right)$. We registered the microhabitat used by each animal at the moment of first sight and measured its morphological variables (nearest $0.1 \mathrm{~mm}$ ). In the laboratory, we registered the number of items of each prey category to the taxonomic level of Order, its dimensions and frequencies. Data showed that, numerically, the category most consumed was Isoptera (84.4\%). Volumetrically, the diet was composed predominantly by Orthoptera (27.5\%) and Isoptera (21.5\%). Prey items that occur aggregated in the environment (termites) were important in the diet of $\mathrm{C}$. ocellifer, a characteristic of active foragers. Males and females did not differ in the types of prey consumed. Cnemidophorus ocellifer had a mean $T_{c}$ in activity of $37.6 \pm 1.6^{\circ} \mathrm{C}$ and the relationship between $T_{c}$ and ambient temperatures $\left(T_{s}\right.$ and $\left.T_{a}\right)$ was positive and significant $\left(F_{2,28}=4.814 ; R^{2}=0.256 ; p<0.05\right)$. Most lizards were first sighted on leaf litter inside shrubs $(45.5 \%)$ and on leaf litter at shrub edge (42.4\%). Cnemidophorus ocellifer had a relatively high mean $\mathrm{T}_{\mathrm{c}}$ during activity, with $\mathrm{T}_{\mathrm{s}}$ explaining most of the variation in lizard $\mathrm{T}_{c}$.
\end{abstract}

KEY WORDS. Bahia; Cnemidophorus; diet; microhabitat; thermal ecology.

Cnemidophorus Wagler, 1830 (Teiidae) is composed of active foraging lizard species distributed throughout much of cisandean South America (ReEDer et al. 2002). These lizards generally occur in open habitats with sandy soil and high temperatures, such as cerrados, Amazonian savannas, caatingas and restingas (SChall \& ResSel 1991, Menezes et al. 2000, Dias \& Rocha 2007). Like other wide foraging species, these lizards need to maintain high body temperatures during activity (Rocha et al. 2009). Cnemidophorus behaviorally regulate their activity temperature at 37-40 C (Bergallo \& Rocha 1993, Magnusson 1993, Teixeira-Filho et al. 1995, Menezes et al. 2000, Mesquita \& Colli 2003a,b) and usually have a diversified diet, although frequently with predominance of insect larvae and termites (PARKER \& Pianka 1975, Pianka 1977, 1986, Magnusson et al. 1985, Bergallo \& Rocha 1994, Dias \& Rocha 2007, Menezes et al. 2008, Mesquita \& Colli 2003 a,b, Teixeira-Filho et al. 2003).

Cnemidophorus ocellifer (Spix, 1825) is a bisexual species and is the most widely distributed species in the ocellifer group, occurring in the Cerrado of central Brazil, in the Caatinga of northeastern Brazil, and in restingas along the northeastern Brazilian coast, from Salvador (Bahia) northwards (VANzolini et al. 1980, Dias \& Rocha 2007). Some aspects of the ecology of $C$. ocellifer have been described for populations from the Caatinga
(VitT 1983a, 1995), Cerrado (Anderson \& VitT 1990, VitT 1991, Vitt \& Carvalho 1995, Mesquita \& Colli 2003a,b) and Atlantic Rainforest (coastal Restinga habitats) (DiAs \& RocHA 2004, 2007) biomes. However, no information regarding populations living in transitional habitats has yet been published. In this study we investigate the diet, thermal ecology and habitat use of a population of $C$. ocellifer at a transitional area between caatinga and "campos rupestres" (rocky fields) habitats in northeastern Brazil.

\section{MATERIAL AND METHODS}

The study was carried out in an area at about $1000 \mathrm{~m}$ elevation in the Morro do Chapéu municipality ( $11^{\circ} 29^{\prime} \mathrm{S}$, $\left.41^{\circ} 07^{\prime} \mathrm{W}\right)$, state of Bahia, northeastern Brazil. The area is at the transition between Caatinga and "campos rupestres" (rocky fields - see EITEN 1992) habitats. The vegetation is predominantly herbaceous and shrubby on rocky and sandy substrates. The climate of the region is warm and dry. During the study period (November-December 2000), mean air temperature was $29.3^{\circ} \mathrm{C}$ and relative air humidity was $48.9 \%$ (values obtained with a thermohygrometer, measured every hour between 7:00 and 17:00 $\mathrm{h}$, under vegetation in the shade, at a height of $1 \mathrm{~m}$ 
above ground). In this area, five other lizard species occur in sympatry with C. ocellifer, the tropidurids Tropidurus hispidus (Spix, 1825), T. erythrocephalus Rodrigues, 1987, T. semitaeniatus (Spix, 1825) and T. cocorobensis Rodrigues, 1987, and the teiid Ameiva ameiva (Linnaeus, 1758).

Lizards were collected from 27 November to 3 December, 2000, with rubber bands and an air rifle, during their period of activity. The collected individuals were euthanized with ether, fixed in formalin (dilution of 1:9) for 48 hours and stored in $70 \%$ ethanol. The microhabitat where each lizard was first seen was recorded according to the following categories: a) leaf litter inside shrubs; b) leaf litter at shrub edges; c) open sand; d) uncovered rocks; e) rocks covered by shrubs; and f) leaf litter outside shrubs. The difference between males and females in the frequency of microhabitats used was tested using a chi-square test (ZAR 1999). For each lizard, we recorded its body temperature $\left(\mathrm{T}_{\mathrm{c}}\right)$, together with air $\left(\mathrm{T}_{\mathrm{a}}\right)(1 \mathrm{~cm}$ above ground $)$ and substrate temperatures $\left(\mathrm{T}_{\mathrm{s}}\right)$, with a quick-reading Schultheis (near $0.2^{\circ} \mathrm{C}$ ) cloacal thermometer. For each individual (prior to fixation), we measured snout-vent length (SVL), head length (HL, measured from posterior margin of tympanum to snout) and head width (HW, taken at the angle of the jaw) using a Vernier caliper (to the nearest $0.1 \mathrm{~mm}$ ), and body mass (to the nearest $0.001 \mathrm{~g}$ ) with an electronic balance. Morphological differences in SVL between males and females were tested using analyses of variance for one factor (ANOVA). The differences in HL and HW between sexes were tested by analysis of covariance (ANCOVA), using SVL as covariate (ZAR 1999). To estimate the activity of $C$. ocellifer at the Morro do Chapéu, we performed hourly transects from 07:00 to 18:00 h during one day, looking for lizards.

In the laboratory, stomach contents were identified and arthropods found were categorized to the taxonomic level of Order. Unidentified arthropod remains were grouped in a separate category "unidentified parts of arthropods" and used only in volumetric analyses. Diet composition was estimated based on relative number, volume, and frequency of each prey type in stomachs. We measured the length and width of each prey with Vernier calipers (to the nearest $0.1 \mathrm{~mm}$ ) and estimated its volume $\left(\mathrm{mm}^{3}\right)$ using the elipsoid formula: $4 / 3 \pi$ (prey length/2)(prey width/2) $)^{2}$. The number of items was counted and the mean length $(\mathrm{mm})$ and mean volume $\left(\mathrm{mm}^{3}\right)$ of the five largest items were estimated for each lizard and related to lizard morphology (head width and head length) by simple regression analyses (ZAR 1999). Due to the wide variation, all these values were log-transformed prior to analysis. A relative importance index $\left(\mathrm{I}_{\mathrm{x}}\right)$ for each prey category was estimated by the sum of the proportional values of volume, number and frequency of occurrence of prey in the diet divided by three (sensu Howard et al. 1999).

Differences between males and females in prey consumption, based on mean length, mean volume and number of prey consumed (log-transformed) were tested by analyses of variance (ANOVA) and by analyses of covariance (ANCOVA) with SVL as covariate (ZAR 1999). The diference between numeric proportions of prey categories consumed by males and females was tested with a Paired t-Test (ZAR 1999).

For females we recorded the number of vitellogenic follicles in each ovary, the size and color of the largest follicle (yellow follicles were considered vitellogenic), the presence and size of corpora lutea, and the number and size of oviductal eggs. We measured the length and width of each egg and estimated its volume using the formula for the elipsoid (DunHam 1983). Females were considered reproductive if they had vitellogenic ovarian follicles or oviductal eggs. Mean clutch size was estimated by averaging the number of oviductal eggs and vitellogenic follicles (when eggs were absent). We considered the simultaneous occurrence of vitellogenic follicles, oviductal eggs or corpora lutea as an evidence of multiple clutches per year in the studied population.

Variations throughout the day in mean body temperatures of lizards in activity and in mean substrate and air temperatures were tested by analysis of variance (ANOVA) (including only samples with $N \geqslant 2$ ) (ZAR 1999). We analyzed the effect of environmental temperatures $\left(\mathrm{T}_{\mathrm{a}} \mathrm{e} \mathrm{T}_{\mathrm{s}}\right.$ ) on lizard body temperature using a multiple regression analysis (ZAR 1999). The effect of lizard SVL and mass on body temperature was also tested by multiple regression analysis (ZAR 1999) and differences in mean body temperature between males and females were tested by analysis of variance (ZAR 1999). Additionally, the tails of all individuals were examined for evidence of previous autotomy and differences between sexes in the frequency of regenerated tails were tested using the $Z$-test for proportions (lizards with broken tails or that lost their tails when captured or handled were ignored).

Results of descriptive statistics are presented throughout the text as mean \pm 1 standard deviation, except for volume and length mean values of the five largest preys, which are presented as mean \pm 1 standard error of mean.

Lizards used for this study were deposited in the herpetological collection of the Museu Nacional, Rio de Janeiro, Brazil (MNRJ 13816-13849).

All data were tested for homocedasticity of variances and for normality of distributions before performing statistical analyses.

\section{RESULTS}

Cnemidophorus ocellifer at the Morro do Chapéu had a mean SVL of $66.0 \pm 7.9 \mathrm{~mm}$ (range 36.0-78.4 mm, $\mathrm{N}=34$ ) and a mean body mass of $7.7 \pm 2.5 \mathrm{~g}$ (range 1.1-12.5 g, $\mathrm{N}=34$ ). Males $(\bar{x}=69.5 \pm 5.7 \mathrm{~mm} \mathrm{SVL}, \mathrm{N}=19)$ were larger than females $(\bar{x}=63.3 \pm 4.2 \mathrm{~mm} \mathrm{SVL}, \mathrm{N}=14)\left(\right.$ ANOVA, $\left.\mathrm{F}_{1,31}=11.53 ; \mathrm{p}=0.002\right)$ (Fig. 1). Males also had wider heads than females (males: $\bar{x}=$ $10.9 \pm 1.2 \mathrm{~mm}, \mathrm{~N}=19$; females: $\overline{\mathrm{x}}=8.9 \pm 0.7 \mathrm{~mm}, \mathrm{~N}=13$ ) (ANCOVA, $\mathrm{F}_{1,29}=58.27 ; \mathrm{p}<0.001$ ).

Cnemidophorus ocellifer consumed 12 different prey categories (Tab. I) and no lizard had an empty stomach. The most 


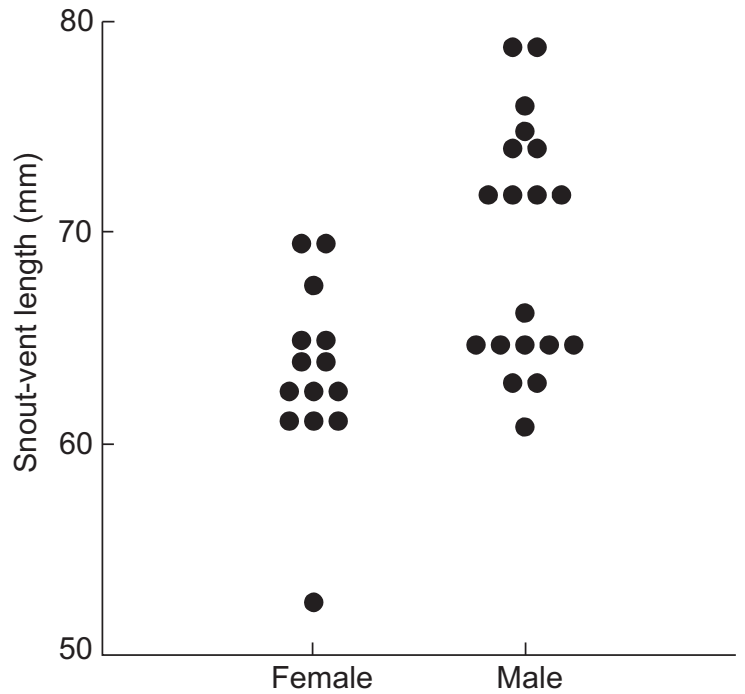

Figure 1. Snout-vent length $(\mathrm{mm})$ of adult males and females of $C$. ocellifer from the Morro do Chapéu, Bahia. frequent items were termites $(71.9 \%)$, orthopterans $(46.9 \%)$, larvae (34.4\%) and spiders (31.2\%). Termites were also the most numerous item, corresponding to $84.4 \%$ of the total of prey consumed $(\mathrm{N}=568$, Tab. I). Volumetrically, the dominant prey types were orthopterans $(27.5 \%)$, termites $(21.5 \%)$ and cockroaches (11.8\%). Termites (59.2) and orthopterans (25.7) were the most important items (highest $\mathrm{I}_{\mathrm{x}}$ ), followed by larvae (15.3) and spiders (13.4). Among larvae, coleopterans were more important than lepidopterans (Tab. I).

Mean volume and mean length of the five largest items and the number of preys consumed were not correlated with body measurements, except for head length which was positively correlated with prey volume (Tab. II). The number of preys consumed per lizard varied from two to $90(\bar{x}=23.2 \pm 23.1$, $\mathrm{N}=29$ ) and males consumed significantly more prey than females (males: $31.6 \pm 27.3, \mathrm{~N}=16$; females: $12.5 \pm 10.6, \mathrm{~N}=12$; ANOVA: $\left.\mathrm{F}_{1,26}=4.469, \mathrm{p}=0.004\right)$, but after removing the effect of body size there was no sex difference in the mean number of ingested prey (ANCOVA: $\mathrm{F}_{1,1,25}=3.732, \mathrm{p}=0.065$ ). The numeric proportion of each prey category did not differ between

Table I. Number, volume, and frequency of prey categories in the diet of $C$. ocellifer $(N=32)$, at the Morro do Chapéu, Bahia. $\left(I_{x}\right)$ relative importance index.

\begin{tabular}{|c|c|c|c|c|c|c|}
\hline Food item & Number & $(\%)$ & Volume & $(\%)$ & Frequency & $I_{x}$ \\
\hline \multicolumn{7}{|l|}{ Arachnida } \\
\hline Aranae & 12 & 1.78 & 587.83 & 7.18 & 31.25 & 13.40 \\
\hline Diplopoda & 4 & 0.59 & 63.09 & 0.77 & 12.50 & 4.62 \\
\hline \multicolumn{7}{|l|}{ Hexapoda } \\
\hline Orthoptera & 19 & 2.82 & 2251.42 & 27.50 & 46.87 & 25.73 \\
\hline Isoptera & 568 & 84.40 & 1758.71 & 21.49 & 71.87 & 59.25 \\
\hline Blattoidea & 5 & 0.74 & 968.53 & 11.83 & 15.62 & 9.40 \\
\hline Hemiptera & 1 & 0.15 & 33.28 & 0.41 & 3.12 & 1.23 \\
\hline Homoptera & 5 & 0.74 & 201.92 & 2.47 & 15.62 & 6.28 \\
\hline \multicolumn{7}{|l|}{ Coleoptera } \\
\hline Adults & 8 & 1.19 & 69.31 & 0.85 & 18.75 & 6.93 \\
\hline Larvae & 14 & 2.08 & 566.53 & 6.92 & 25.00 & 11.33 \\
\hline Neuroptera Larvae & 1 & 0.15 & 2.49 & 0.03 & 3.12 & 1.10 \\
\hline Hymenoptera Formicidae & 4 & 0.59 & 1.88 & 0.02 & 9.37 & 3.33 \\
\hline \multicolumn{7}{|l|}{ Lepidoptera } \\
\hline Adults & 2 & 0.30 & 9.95 & 0.12 & 6.25 & 2.22 \\
\hline Larvae & 3 & 0.45 & 154.55 & 1.89 & 9.37 & 3.90 \\
\hline Total of larvae & 19 & 2.83 & 724.16 & 8.85 & 34.37 & 15.30 \\
\hline Insect eggs & 10 & 1.49 & 109.3 & 1.34 & 9.37 & 4.06 \\
\hline Unidentified arthropods & & & 1067.46 & 13.04 & & \\
\hline \multicolumn{7}{|l|}{ Plant material } \\
\hline Flowers & 15 & 2.23 & 338.21 & 4.13 & 21.87 & 9.41 \\
\hline Seeds & 1 & 0.15 & 0.68 & 0.01 & 3.12 & 1.09 \\
\hline Total & 673 & & 8185.73 & & & \\
\hline
\end{tabular}


Table II. Regression statistics relating lizard morphology (log-transformed) to number, mean length ( $\mathrm{mm}$ ) and mean volume of the five largest prey items of $C$. ocellifer at the Morro do Chapéu.

\begin{tabular}{lccc}
\hline & Number of prey & Mean length of five largest prey & Mean volume of the five largest prey \\
\hline Head width & $F 1.27=0.360, p=0.553$ & $F 1.27=0.000, p=0.991$ & $F 1.27=1.854, p=0.185$ \\
Head length & $F 1.27=0.850, p=0.365$ & $F 1.27=0.254, p=0.618$ & $F 1.27=5.939, p=0.022$ \\
\hline
\end{tabular}

males and females of C. ocellifer (Paired t-Test; $\mathrm{t}=1.000, \mathrm{df}=13$, $\mathrm{p}>0.05$ ) (Tab. III). Mean prey volume was $\bar{x}=43.5 \pm 13.4 \mathrm{~mm}^{3}$ $(\mathrm{N}=29)$ and males and females ingested similar volumes of prey (males: $35.3 \pm 8.4 \mathrm{~mm}^{3}, \mathrm{~N}=16$; females: $57.7 \pm 30.6 \mathrm{~mm}^{3}$, $\mathrm{N}=12$; ANOVA: $\left.\mathrm{F}_{1,26}=0.022, \mathrm{p}=0.883\right)$. Mean prey length was $\overline{\mathrm{x}}=6.4 \pm 0.5(\mathrm{~N}=29)$, with no differences between sexes (males: $5.7 \pm 0.4 \mathrm{~mm}, \mathrm{~N}=16$; females: $7.5 \pm 1.0 \mathrm{~mm}, \mathrm{~N}=12 ; \mathrm{F}_{1,26}=2.312$; $\mathrm{p}=0.140)$.

Table III. Diet composition by number (\% in parenthesis) of prey consumed by males $(N=16)$ and females $(N=12)$ of $C$. ocellifer at the Morro do Chapéu.

\begin{tabular}{lrcc}
\hline \multicolumn{1}{c}{ Prey types } & \multicolumn{2}{c}{ Males } & Females \\
\hline Isoptera & $458(90.3)$ & $94(63.5)$ \\
Orthoptera & 11 & $(2.2)$ & $8(5.4)$ \\
Coleoptera & 7 & $(1.4)$ & $1(0.7)$ \\
Larva & 6 & $(1.2)$ & $11(7.4)$ \\
Flower & 6 & $(1.2)$ & $9(6.1)$ \\
Aranae & $6(1.2)$ & $6(4.1)$ \\
Hymenoptera (Formicidae) & 3 & $(0.6)$ & $1(0.7)$ \\
Lepidoptera & 2 & $(0.4)$ & $0(0.0)$ \\
Blattaria & 2 & $(0.4)$ & $3(2.0)$ \\
Diplopoda & 2 & $(0.4)$ & $2(1.4)$ \\
Insect eggs & 1 & $(0.2)$ & $9(6.1)$ \\
Homoptera & $1(0.2)$ & $4(2.7)$ \\
Seed & $1(0.2)$ & $0(0.0)$ \\
Hemiptera & $1(0.2)$ & $0(0.0)$ \\
\hline
\end{tabular}

Mean SVL of reproductive females was $63.4 \pm 4.4 \mathrm{~mm}$ (range 52.5-69.9 mm, $\mathrm{N}=13$ ). Clutch size averaged $2.7 \pm 1.6$ (range $=1-6, N=11$, vitellogenic follicles). For females bearing oviductal eggs, mean egg volume was $494.1 \pm 40.4 \mathrm{~mm}^{3}$ (range $=458.5-538.1, \mathrm{~N}=3$ ) for the eggs in the right oviduct and $421.4 \pm 37.8 \mathrm{~mm}^{3}$ (range $=381.2-456.3$ ) for the eggs in the left oviduct. Only one female simultaneously bore oviductal eggs and vitellogenic follicles.

The first active C. ocellifer was observed at 7:00 $\mathrm{h}$ and, from then on, the number of active lizards increased until a maximum between 10:00 $\mathrm{h}$ and 14:00 $\mathrm{h}$, decreasing afterwards
(Fig. 2). After 16:00 h no active C. ocellifer was seen. Mean body temperature in activity was $37.6 \pm 1.6^{\circ} \mathrm{C}$ (range 34.0 to $40.8^{\circ} \mathrm{C}$, $\mathrm{N}=29$ ). Mean body temperature did not vary throughout the activity period $\left(\mathrm{F}_{8,21}=0.574, \mathrm{p}=0.747\right)$. Most $(75.9 \%)$ lizards had body temperatures above $37.0^{\circ} \mathrm{C}$. Mean body temperature did not differ between males and females $\left(\mathrm{F}_{1,28}=0.119\right.$, $\mathrm{p}=0.733$ ). Mean air temperature was $30.7 \pm 2.3^{\circ} \mathrm{C}$ (range 25.0$36.6^{\circ} \mathrm{C}, \mathrm{N}=31$ ) and mean substrate temperature was $33.0 \pm$ $3.4^{\circ} \mathrm{C}\left(26.0-42.0^{\circ} \mathrm{C}, \mathrm{N}=31\right)$. Mean air temperature $\left(\mathrm{F}_{8,21}=1.093\right.$, $\mathrm{p}=0.406)$ and mean substrate temperature $\left(\mathrm{F}_{8,21}=2.150\right.$, $\mathrm{p}=0.077$ ) did not vary throughout the day (Figs 3-5). Relationship between lizard body temperature and environmental temperatures (air and substrate) was positive and significant $\left(\mathrm{F}_{2,28}=4.814 ; \mathrm{R}^{2}=0.256 ; \mathrm{p}=0.016\right)$, but only substrate temperature $(p=0.035)$ explained an additional portion of the variation in body temperature. Body temperature was not significantly $(\mathrm{p}>0.05)$ related to lizard SVL and body mass.

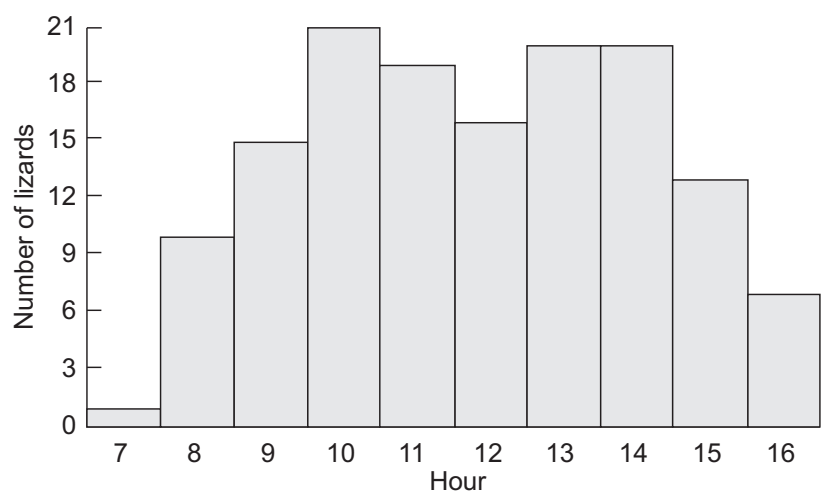

Figure 2. Activity period of C. ocellifer at the Morro do Chapéu, Bahia, during a single sunny day, with mean air temperature of $29.2 \pm 4.2^{\circ} \mathrm{C}$ and mean relative air humidity of $50.0 \pm 13.9 \mathrm{~mm}$.

The main microhabitats used by C. ocellifer at Morro do Chapéu were leaf litter inside shrubs (45.5\%) and leaf litter at shrub edge (42.4\%) (Fig. 6). We saw no C. ocellifer on rocky substrates. Males and females did not differ in the proportion of microhabitats utilized (chi-square $=0.111, \mathrm{p}=0.739$ ).

The frequency of regenerated tail was $33.3 \%$ (10/30), not significantly different between males (5/16) and females (5/ 13) $(\mathrm{Z}=-0.406, \mathrm{p}=0.342)$. 

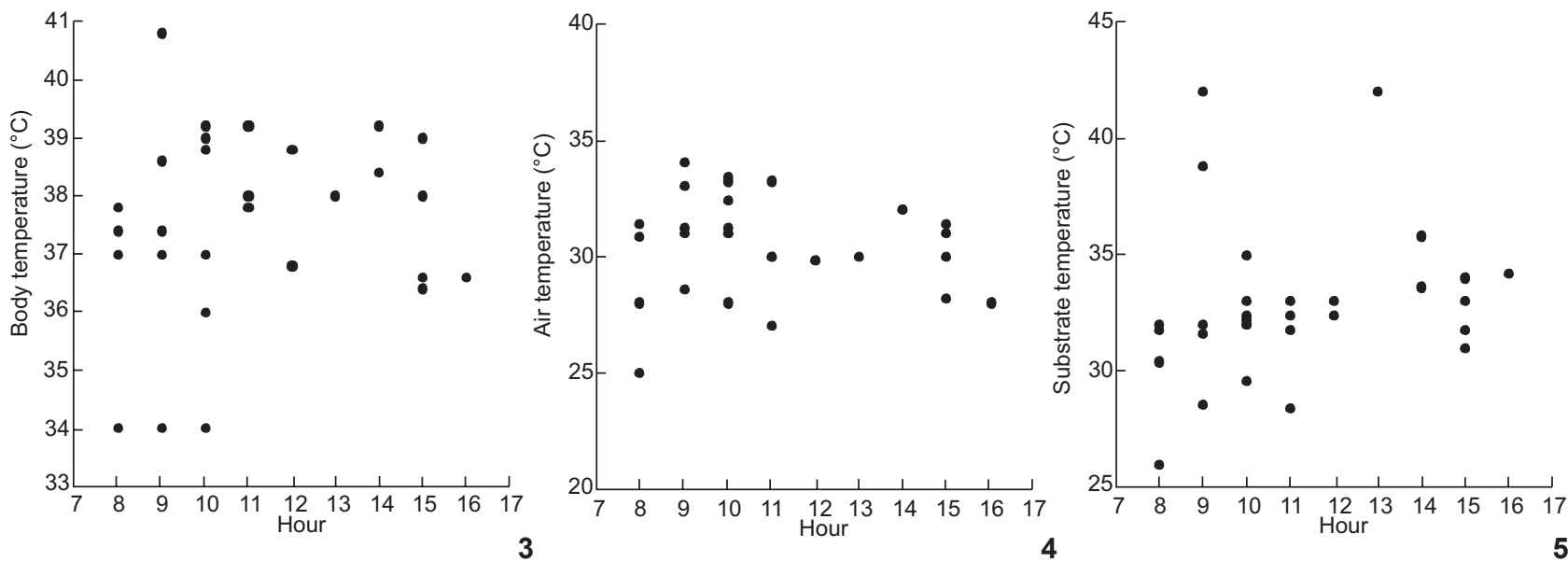

Figures 3-5. Body temperatures recorded during activity of $\mathrm{C}$. ocellifer (3) and air (4) and substrate (5) temperatures $\left({ }^{\circ} \mathrm{C}\right)$ throughout the day in the Morro do Chapéu, Bahia. Dots represent observations in different days.

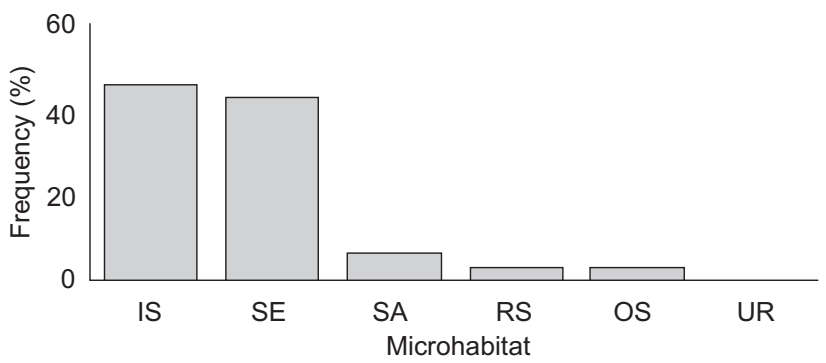

Figure 6. Frequency of the different types of microhabitats used by individuals of $C$. ocellifer at the Morro do Chapéu, Bahia, Brazil. (IS) Leaf litter inside shrubs, (SE) leaf litter at shrub edge, (SA) open sand, (RS) rocks covered by shrubs, (OS) leaf litter outside shrubs, (UR) uncovered rocks, $\mathrm{N}=33$.

\section{DISCUSSION}

Diet of C. ocellifer in Morro do Chapéu was composed mainly by arthropods, with isopterans, orthopterans, larvae and cockroaches being the dominant items. Isopterans have low mobility and occur aggregated in the environment, being frequently preyed upon by active foraging lizards (e.g. PIANKA 1986, Bergallo \& Rocha 1993, Eifler \& Eifler 1998, Zaluar \& Rocha 2000, Mesquita \& Colli 2003a, Teixeira-Filho et al. 2003, Dias \& Rocha 2007). Insect larvae also have low mobility and high nutritive value, being sometimes found grouped on leaves and plant stems (PIANKa 1986). Isopterans and larvae are usually consumed in high proportions by Cnemidophorus spp. (e.g. Bergallo \& Rocha 1993, Vitt \& Carvalho 1995, Vitt et al. 1997, Mesquita \& Colli, 2003a, Teixeira-Filho et al. 2003, Dias \& Rocha 2007, Menezes et al. 2008) and, in general, are important sources of energy and hydric balance for lizards (NAGY et al. 1984, ANDERSON \& KARASOV 1988). Because active foraging lizards usually rely on chemical cues to detect and recognize their prey (CooPER 1990), they are efficient in finding preys with low mobility, which live in the leaf litter or in the upper soil layer (such as termites, insect larvae, and spiders). Cockroaches and spiders also constitute important preys for C. ocellifer from other populations (MESQUita \& Colli 2003a, Dias \& Rocha 2007), and also for other Cnemidophorus species (e.g. VitT 1991, MAGNusson \& Silva 1993, VitT et al. 1993, 1999, Dias \& Rocha 2007, Menezes et al. 2006, 2008), with some exceptions (Mesquita \& Colli 2003b).

Plants are an important source of water to omnivorous and herbivorous lizards in environments with little availability of free water (e.g. Schall \& Ressel 1991, Rocha 1996a, 2000). The consumption of plant material has been reported for different species of active foraging lizards, including Cnemidophorus species (e.g. Schall \& Ressel 1991, Magnusson \& Silva 1993, Paulissen \& Walker 1994, Schall \& Dearing 1994, Vitt et al. 1997, Schall 2000, Dias \& Rocha 2007). At the Morro do Chapéu, flowers were the fifth most frequent item (21.9\%) in the diet of C. ocellifer. This fact, associated with the presence of intact flowers in stomachs, does not support the hypothesis of accidental ingestion during capture of insects. All flowers found in the stomachs were identical (Cassia sp.).

The fact that no individuals examined had empty stomachs suggests that the population is in a positive energetic balance (sensu Huey et al. 2001). In general, Cnemidophorus lizards have low proportions of individuals with empty stomachs e.g. 3.0\% for C. nativo Rocha, Bergallo \& Peccinini-Seale, 1997 (Menezes et al. 2008), 2.9\% for C. littoralis Rocha, Araújo, Vrcibradic \& Costa, 2000 (Teixeira-Filho et al. 2003).

Despite the apparent differences among sexes in the number of prey consumed, the statistics showed that when the effect of body size was removed from the analysis, no differences were detected. So, for this C. ocellifer population we can infer 
that there are no differences among sexes in mean number of prey consumed. Similarly, the frequency of occurrence of prey categories did not differ among sexes, indicating that the diet of males and females are also similar qualitatively, in spite of the larger body size of males compared to females.

The mean number and mean length of prey of C. ocellifer in Morro do Chapéu were similar to those reported for the unisexual C. nativo in Guaratiba, Bahia, $\overline{\mathrm{x}}_{\text {number of preys }}=23.0 \pm$ $2.8, \bar{x}_{\text {prey length }}=8.2 \pm 0.4$ (Menezes et al. 2008), and for the bisexual C. deppii Wiegmann, 1834 in Nicaragua, $\overline{\mathrm{x}}_{\text {number of preys }}=$ $16.7 \pm 5.1 ; \bar{x}_{\text {prey length }}=4.4 \pm 0.2$ (ViTT et al. 1993). However, mean prey volume for C. ocellifer in the Morro do Chapéu (Bahia) was higher than other cogeneric species, e.g. C. nativo: $\overline{\mathrm{x}}=20.4$ \pm 2.2 Menezes et al. (2008) and C. deppii: $\bar{x}=15.0 \pm 2.6$ (VITt et al. 1993). This difference can be associated to the greater consumption of orthopterans (large and voluminous prey) in the Morro do Chapéu when compared to the other cited species (VitT et al. 1993, Menezes et al. 2008). In general, prey size varies among lizard species and body size of the lizards explains some of this variation (MAGNusson et al. 1985, VITT \& ZANI 1998). However, in terms of number of prey, larger lizard species do not necessarily eat more prey items (VITT \& ZANI 1998). In Cnemidophorus spp., on the contrary, this is not always the case. As Cnemidophorus spp. generally feed on large quantities of Isoptera, the proportion of termites influence the mean prey size per lizard species/population. In general, there is no relation between number, length and mean volume of the prey and the morphology in many species of Cnemidophorus (e.g. Vitt et al. 1997, Mesquita \& Colli 2003a,b, Teixeira-Filho et al. 2003, Dias \& Rocha 2007, Menezes et al. 2008), a consequence of the consumption of large numbers of isopterans, small prey with little variation in body size (Mesquita \& Colli 2003a, Teixeira-Filho et al. 2003, Dias \& Rocha 2007, Menezes et al. 2008).

Mean clutch size of $C$. ocellifer at the Morro do Chapéu was similar to that of other conspecific populations and congeneric species in South America, suggesting that clutch size may be phylogenetically restricted for most species [e.g. C. ocellifer in Brazilian cerrado (2.3 - VITT 1991; 2.0 - MesQuita \& Colli 2003a) and caatinga (2.7 - VITT 1983a); C. nativo in northeastern Brazil (2.2 - Menezes et al. 2004); C. lemniscatus (LinNAEus 1758) in Cumaná, Venezuela (2.6 - Fiтch 1985); C. lacertoides Duméril \& Bibron 1839 in Córdoba, Argentina (3.0 - Aún \& MARTORI 1996)], although there are some exceptions of species with a fixed clutch size of a single egg (e.g. C. mumbuca - ColuI et al. 2003 and C. jalapensis - Colli et al. 2009).

There is sexual dimorfism in body size and head width (males had greater values than females in both cases), similar to other species/populations of Cnemidophorus in Brazil (VITT 1983a, VitT et al. 1997, Rocha et al. 2000, Mesquita \& Colli 2003b, Teixeira-Filho et al. 2003, Dias \& Rocha 2007). This can be related to the fact that larger bodies and jaws may confer an advantage during intraspecific male-male agonistic interactions (e.g. Vitt 1983a, Anderson \& Vitt 1990, Rocha 1996b).
Frequency of regenerated tails in C. ocellifer from the Morro do Chapéu was relatively low when compared to other species of active foraging lizards [e.g. 62.3\% in Vanzosaura rubricauda (Boulenger, 1902) - VITT 1983b; 83.3\% in Mabuya agilis (RADDI 1823) - VRCIBRADIC \& Rocha 2002; 82.4\% in Mabuya frenata (Cope 1862) - VAN SLuYs et al. 2002]. Nevertheless, it was similar to those reported for other cnemidophorines [e.g. 38.4\% in C. ocellifer - VITT 1983b; 25.9\% in Ameiva ameiva ZANI 1996; 27.2\% in Aspidoscelis sexlineata (Linnaeus 1766) - FiтcH 2003]. This similarity in tail break frequencies among cnemidophorines may be due to phylogenetic similarities in ease of tail shedding. Tail loss in lizards is a highly complex process and affects several physiological activities (DANIELs 1983). As a consequence, loss of tail (whole or part of it) can be energetically expensive, particularly so during the breeding season, because of their potential role as energy storage for reproduction (VITT \& Cooper 1986). Similarly, tail loss also impairs locomotion and reduces escape speed in some species (BALLINGER et al. 1979, BRown et al. 1995).

Body temperatures of active C. ocellifer in the Morro do Chapéu were similar to those recorded for other populations (Dias \& Rocha 2004, Mesquita \& Colli 2003a, Vitt 1995) and also for other species of Cnemidophorus (VitT \& CARVALHo 1995, Teixeira-Filho et al. 1995, Menezes et al. 2000, Dias \& Rocha 2004). Our data is in agreement with the idea of Bogert (1949) and SCHALl (1977) that closely related lizards tend to have similar body temperatures even living in different habitats or geographical areas. In the Morro do Chapéu, at least the two measured environmental sources of heat (substrate and air) were associated with body temperature of C. ocellifer. Substrate and air temperatures jointly explained about $26 \%$ of the variation in the lizard body temperature, but only substrate temperature explained an additional portion of lizard body temperature. This is suggestive that direct insulation (which was not measured here) may also play an important role together with air and substrate temperature. For this population, mean activity temperature was not influenced by lizard size or body mass, similar to other species of lizards (e.g. SMITH \& BALLINGER 1994, VRCibradic \& Rocha 1998, Kiefer et al. 2005, IbARgÜEngoytía 2005).

Lack of sexual dimorphism in body temperature of $C$. ocellifer can be related, among other factors, to the similarity in use of different microhabitats in the study area. Cnemidophorus lizards normally occur in environments with sandy soils and where humidity is relatively low. In these environments, they generally forage in open places such as shrub edges (Teixeira-Filho et al. 1995, Menezes et al. 2000, Mesquita \& Colli 2003a, Dias \& Rocha 2007). The high frequency with which $C$. ocellifer in the Morro do Chapéu used the interior of shrubs suggests that this microhabitat may provide an appropriate thermal and foraging environment as well as shelter from potential predators.

We conclude that $C$. ocellifer at the Morro do Chapéu is an omnivorous lizard that preferentially consumes termites and 
orthopterans. Sexes do not differ in the types of consumed prey. Mean body temperature while active is relatively high, as expected for an active foraging lizard. Ecology of C. ocellifer at the Morro do Chapéu, despite representing a population living in a transitional habitat, did not differ much from previous reports for other conspecific populations.

\section{ACKNOWLEDGMENTS}

This study is part of the Programa de Ecologia, Conservação e Manejo de Ecossistemas do Sudeste Brasileiro and of the Projeto Ecologia de Répteis do Leste Brasileiro, both of the Departamento de Ecologia, Instituto de Biologia, Universidade do Estado do Rio de Janeiro. We thank the Conselho Nacional de Desenvolvimento Científico e Tecnológico for research grants to C.F.D.R. (304791/20010-5 and 470265/2010-8), to M.V.S. (307773/20086 and 479874/2001-8) and a Graduate fellowship to V.A.M. and to A.F.F., the Fundação de Amparo à Pesquisa do Estado do Rio de Janeiro for research grants to M.V.S. (E-26/172.383/2000). CFDR also received a grant from the Fundação Carlos Chagas Filho de Amparo à Pesquisa do Estado do Rio de Janeiro (through the Programa Cientistas do Nosso Estado, Process E-26/ 102.404.2009). Currently VAM is associated to the Programa de Pós-Graduação em Ecologia of the Universidade do Estado do Rio de Janeiro and receives a Post-Doctoral grant from the FAPERJ. We are grateful to D. Vrcibradic for the review of the manuscript.

\section{LITERATURE CITED}

Anderson, R.A. \& W.H. Karasov. 1988. Energetics of the lizard Cnemidophorus tigris and life history consequences of foodacquisition mode. Ecological Monographs 58: 79-110.

Anderson, R.A. \& L.J.Vitt. 1990. Sexual selection versus alternative causes of sexual dimorphism in teiid lizards. Oecologia 84: 145-157.

Aún, L. \& R.Martori. 1996. Características de la biología de Cnemidophorus serranus y Cnemidophorus lacertoides. Cuadernos de Herpetología 9: 95-99.

Ballinger, R.E.; J.W. Nietfeldt \& J.J. Krupa. 1979. An experimental analysis of the role of the tail in attaining high speed in Cnemidophorus sexlineatus (Reptilia: Squamata: Lacertilia). Herpetologica 35: 114-115.

Bergallo, H.G. \& C.F.D. Rocha. 1993. Activity pattern and body temperature of two sympatric lizards with differents foraging tactics in southeastern Brazil. Amphibia-Reptilia 14: 312315.

Bergallo, H.G. \& C.F.D. Rocha. 1994. Spatial and trophic niche differentiation in two sympatric lizards (Tropidurus torquatus and Cnemidophorus ocellifer) with different foraging tactics. Australian Journal of Ecology 19: 72-75.

Bogert, C.M. 1949. Thermorregulation in reptiles, a factor in evolution. Evolution 3: 196-211.

Brown, R.M.; D.H. TAYLOR \& D.H. Gist. 1995. Effect of caudal autotomy on locomotor perfor-mance of wall lizards (Podarcis muralis). Journal of Herpetology 29: 98-105.

Colli, G.R.; J.P. Caldwell; G.C. Costa; A.M. Gainsbury; A.A. Garda; D.O. Mesquita; C.M.R. Monteiro Filho; A.H.B. Soares; V.N.E. Silva; P.H.Valdujo; G.H.C. Vieira; L.J. VitT; F.P. Werneck; H.C. Wiederhecker \& M.G. Zatz. 2003. A new species of Cnemidophorus (Squamata, Teiidae) from the Cerrado biome in central Brazil. Occasional Papers of the Oklahoma Museum of Natural History 14: 1-14.

Colli G. R.; L.G. Giugliano; D.O. Mesquita \& F.G.R. França. 2009. A new species of Cnemidophorus from the Jalapão region, in the central Brazilian Cerrado. Herpetologica 65: 311-327.

Cooper, W.E. 1990. Prey odor detection by teiid and lacertid lizards and the relationship of prey odor detection to foraging mode in lizard families. Copeia 1990: 237-242.

Daniels, C.B. 1983. Running: an escape strategy enhanced by autotomy. Herpetologica 39 (2): 162-165.

Dias, E.J.R. \& C.F.D. Rocha. 2004. Thermal ecology, activity patterns, and microhabitat use by two sympatric whiptail lizards (Cnemidophorus abaetensis and Cnemidophorus ocellifer) from northeastern Brazil. Journal of Herpetology 38 (4): 586-588.

Dias, E.J.R. \& C.F.D. Rocha. 2007. Niche differences between two sympatric whiptail lizards (Cnemidophorus abaetensis. e C. ocellifer, Teiidae) in the restinga habitat of northeastern Brazil. Brazilian Journal of Biology 67 (1): 41-46.

Dunham, A.E. 1983. Realized niche overlap, resource abundance, and intensity of interspecific competition, p. 261-280. In: R.B. Pianka \& T. Schoener (Eds). Lizard Ecology: Studies of a Model Organism. Cambridge, Harvard University Press.

EIfler, D.A. \& M.A. EIfLer. 1998. Foraging behavior and spacing patterns of the lizard Cnemidophorus uniparens. Journal of Herpetology 32: 24-33.

EITEN, G. 1992. Natural Brazilian vegetation types and their causes. Anais da Academia Brasileira de Ciências 64 (1): 35-65.

Fiтch, H.S. 1985. Variation in clutch and litter size in New World reptiles. University of Kansas Museum of Natural History, Miscellaneous Publication 76:1-76.

Fiтch, H.S. 2003. A comparative study of loss and regeneration of lizard tails. Journal of Herpetology 37 (2): 395-399.

Howard, A.K.; J.D. Forester; J.M. Ruder; J.S. Parmerlee \& R. Powell. 1999. Natural history of a terrestrial Hispaniolan anole, Anolis barbouri. Journal of Herpetology 33: 702-706.

Huey, R.B.; E.R. Pianka \& L.J. Vitt. 2001. How often do lizards "run on empty"? Ecology 82 (1): 1-7.

IbARgÜEngoytía, N.R. 2005. Field, selected body temperature and thermal tolerance of the syntopic lizards Phymaturus patagonicus and Liolaemus elongatus (Iguania: Liolaemidae). Journal of Arid Environments 62 (3): 435-448.

Kiefer, M.C.; M. Van Sluys \& C.F.D. Rocha. 2005. Body temperatures of Tropidurus torquatus (Squamata, Tropiduridae) from coastal populations: Do body temperatures vary along their geographic range? Journal of Thermal Biology 30: 449-456. 
Magnusson, W.E. 1993. Body temperature of field active Amazonian Savana lizards. Journal of Herpetology 27 (1): 53-58.

Magnusson, W.E.; L.J.D. Paiva; R.M.D. Rocha; C.R. Franke; L.A. KASPER \& A.P. LIMA. 1985. The correlates of forraging mode in a community of Brazilian lizards. Herpetologica 41 (3): 324-332.

Magnusson, W.E. \& E.V. Silva. 1993. Relative effects of size, season and species on the diets of some Amazonian savanna lizards. Journal of Herpetology 27 (4): 380-385.

Menezes, V.A.; C.F.D. Rocha \& G.F. Dutra. 2000. Termorregulação no lagarto partenogenético Cnemidophorus nativo (teiidae) em uma área de restinga do nordeste do Brasil. Revista de Etologia 2: 103-109.

Menezes, V.A.; C.F.D. Rocha \& G.F. Dutra. 2004. Reproductive ecology of the parthenogenetic whiptail lizard Cnemidophorus nativo in a Brazilian restinga habitat. Journal of Herpetology 38 (2): 280-282.

Menezes, V.A.; V.C. Amaral; M. Van Sluys \& C.F.D. Rocha. 2006. Diet and foraging of the endemic lizard Cnemidophorus littoralis (Squamata, Teiidae) in restinga of Jurubatiba, Macaé - RJ. Brazilian Journal of Biology 66 (3): 803-807.

Menezes, V.A.; G.F. Dutra \& C.F.D. Rocha. 2008. Feeding habits of the endemic tropical parthenogenetic lizard Cnemidophorus nativo (Teiidae) in a restinga area of the northeastren Brazil. Journal of Natural History 42 (39-40): 2575-2583.

Mesquita, D.O. \& G.R. Colli. 2003a. The ecology of Cnemidophorus ocellifer (Squamata, Teiidae) in a Neotropical Savanna. Journal of Herpetology 37 (3): 498-509.

Mesquita, D.O. \& G. R. Colli. 2003b. Geographical variation in the ecology of populations of some Brazilian species of Cnemidophorus (Squamata, Teiidae). Copeia 2003: 285-298.

Nagy, K.A.; R.B. Huye \& A.F. BennetT. 1984. Field energetics and forraging mode of Kalahari lacertid lizards. Ecology 65 (2): 588-596.

Parker, W.S. \& E.R. Pianka. 1975. Comparative ecology of populations of the lizard Uta stansburiana. Copeia 1975: 615-632.

Paulissen, M.A. \& J.M. WALKer. 1994. Diet of the insular whiptail lizard Cnemidophorus nigricolor (Teiidae) from Grand Rockes Island, Venezuela. Journal of Herpetology 28 (4): 524-526.

PIANKA, E.R. 1977. Reptilian species diversity, p. 1-34. In: C. Gans \& D.W. Tinkle (Eds). Biology of the Reptilia. New York, Academic Press, vol.12, 536p.

PIANKA, E.R. 1986. Ecology and Natural History of Desert Lizards. New Jersey, Princeton University Press, 201p.

Reeder, T.W.; C.J. Cole \& H.C. Dessauer. 2002. Phylogenetic relationships of whiptail lizards of the genus Cnemidophorus (Squamata: Teiidae): a test of monophyly, reevaluation of karyotypic evolution, and review of hybrid origins. American Museum Novitates 3365: 1-61.

Rocha, C.F.D. 1996a. Seasonal shift in the diet: the seasonality in food resouces affecting the diet of Liolaemus lutzae
(Tropiduridae). Ciência e Cultura Journal of the Brazilian Association for the Advancement of Science 48 (4): 264269.

Rосна, C.F.D. 1996b. Sexual dimorphism in the lizard Liolaemus lutzae of southeastern Brazil, p. 131-140. In: J.E. PÉFAur (Ed.) Herpetologica Neotropical, Actas del II Congresso Latinoamericano de Herpetologia.Merida, Consejo de Publicaciones, Uniiversidad de Los Andes, vol. 2.

Rocha, C.F.D. 2000. Biogeografia de répteis de restingas: distribuição, ocorrência e endemismos, p. 99-116. In: F.A. EsTEves \& L.D. LACERDA (Eds). Ecologia de Restingas e Lagoas Costeiras. Macaé, NUPEM/UFRJ.

Rocha, C.F.D.; A.F.B. Araújo; D. Vrcibradic \& E.M.M. Costa. 2000. New Cnemidophorus (Squamata; Teiidae) from coastal Rio de Janeiro state, southeastern Brazil. Copeia 2000: 501-509.

Rocha, C.F.D.; M. Van Sluys; D. Vrcibradic; M.C. Kiefer; V.A. Menezes \& C.C. Siqueira. 2009. Comportamento de termorregulação em lagartos brasileiros. Oecologia Brasiliensis 13 (1): 115-131.

SCHALL, J.J. 1977. Thermal ecology of five sympatric species of Cnemidophorus (Sauria: Teiidae). Herpetologica 33: 261-272

SCHALL, J.J. 2000. Learning in free-ranging population of the whiptail lizard Cnemidophorus murinus. Herpetologica 56 (1): $38-45$.

Schall, J.J. \& D.D. Dearing. 1994. Body temperature of herbivorous Bonaire Island whiptail lizard (Cnemidophorus murinus). Journal of Herpetology 28 (4): 526-528.

Schall, J.J. \& S. Ressel. 1991. Toxic plant compounds and the diet of the predominantly herbivorous lizard, Cnemidophorus arubensis. Copeia 1991: 111-119.

Smith, G.R. \& R.E. BaLlinger. 1994. Thermal ecology of Sceloporus virgatus from southeastern Arizona, with comparison to Urosaurus ornatus. Journal of Herpetology 28: 65-69.

Teixeira-Filho, P.F.; C.F.D. Rocha \& S.C. Ribas. 1995. Aspectos da ecologia termal e uso do hábitat por Cnemidophorus ocellifer (Sauria: Teiidae) na restinga de Barra de Maricá, RJ. Oecologia Brasiliensis 1: 155-165.

Teixeira-Filho, P.F.; C.F.D. Rocha \& S.C. Ribas. 2003. Relative feeding specialization may depress ontogenetic, seasonal and sexual variations in diet: the lizard Cnemidophorus littoralis (Teiidae). Brazilian Journal of Biology 63 (2): 321-328.

Van Sluys, M.; D. Vrcibradic \& C.F.D. Rocha. 2002. Tail loss in the syntopic lizards Tropidurus itambere (Tropiduridae) and Mabuya frenata (Scindae) in southeastern Brazil. Studies on Neotropical Fauna and Environment 37: 227-231.

Vanzolini P.E.; A.M.M. Ramos-Costa \& L.J. Vitt 1980. Répteis das Caatingas. Rio de Janeiro, Academia Brasileira de Ciências, $161 \mathrm{p}$.

VITT, L.J. 1983a. Reproduction and sexual dimorphism in the tropical teiid lizard Cnemidophorus ocellifer. Copeia 1983: 359-366.

VITT, L.J. 1983b. Tail loss in lizards: the significance of foraging and predator escape modes. Herpetologica 39 (2): 151-162. 
VITT, L.J. 1991. An introduction of the ecology of Cerrado lizards. Journal of Herpetology 25 (1): 79-90.

VITT, L.J. 1995. The ecology of tropical lizards in the Caatinga of northeast Brazil. Occasional Papers of the Oklahoma Museum of Natural History 1: 1-29.

VitT, L.J. \& C.M. CarvalHo. 1995. Niche partioning in a tropical wet season: lizards in the Lavrado area of northern Brazil. Copeia 2: 305-329.

VITT, L.J. \& W.E. COOPER JR. 1986. Tail loss, tail color, and predator escape in Eumeces (Lacertilia: Scincidae): age-specific differences in costs and benefits. Canadian Journal of Zoology 64 (3): 583-592. doi:10.1139/z86-086.

VitT, L.J. \& P.A. Zani. 1998. Ecological relationships among sympatric lizards in a sucessional landscape in the northern Amazon of Brazil. Journal of Tropical Ecology 14: 63-86.

VitT, L.J.; P.A. Zani; J.P. Caldwell \& R.D. DurTsche. 1993. Ecology of the whiptail lizard Cnemidophorus deppii on a tropical beach. Canadian Journal of Zoology 71: 2391-2400.

VitT, L.J.; P.A. Zani; J.P. Caldwell; M.C. Araújo \& W.E. Magnusson. 1997. Ecology of whiptail lizards (Cnemidophorus) in the Amazon Region of Brazil. Copeia 4: 745-757.

Submitted: 30.X.2009; Accepted: 02.I.2011.

Editorial responsibility: Ana Lúcia da C. Prudente
VitT, L.J.; P.A. ZANI \& M.C. Espósito. 1999. Historical ecology of Amazonian lizards: implications for community ecology. Oikos 87: 286-294.

VRCibradic, D. \& C.F.D. Rocha. 1998. Reproductive cycle and life-history traits of the viviparous skink Mabuya frenata in southeastern Brazil. Copeia 1998: 612-619.

VRcibradic, D. \& C.F.D. Rocha. 2002. Use of cacti as heat sources by thermoregulating Mabuya agilis (Raddi) and Mabuya macrorhyncha Hoge (Lacertilia, Scincidae) in southeastern Brazil. Revista Brasileira de Biologia 19: 77-83.

Zaluar, H.L.T. \& C.F.D. Rocha. 2000. Ecology of the wide foraging lizard Ameiva ameiva (Teiidae) in a sand dune habitat of southeast Brazil: Ontogenetic, sexual and seasonal trends in food habits, activity, thermal biology and microhabiat use. Ciência e Cultura Journal of the Brazilian Association for the Advancement of Science 52 (2): 101107.

ZANI, P. 1996. Patterns of caudal-autotomy evolution in lizards. Journal of Zoology 240: 201-220.

ZAR, J.H. 1999. Biostatistical Analysis. Upper Saddle River, Prentice Hall, $4^{\text {th }}$ ed., XII+663p. 